\title{
Financial Market Development, Economic Development and Growth Diagnostics: An Application to Peru
}

Sudhakar Raju, Rockhurst University, USA

Brian Fitzpatrick, Rockhurst University, USA

\begin{abstract}
The purpose of this paper is two fold. First, we hope that the analysis contained here will provide policymakers in Peru with a guidepost to framing appropriate financial and economic policy. Second, we hope to offer policymakers everywhere a template to implement a similar type of "growth diagnostic" for their respective countries. In this paper we find that the macro and micro-economic milieu in Peru constitutes a binding constraint and relieving this constraint would lead to significant economic growth. A recent World Bank study and a World Economic Forum survey confirm our general findings. In addition, our analysis indicates the following: Peru is not savings or investment constrained in either domestic or international markets; Peru is clearly constrained by a lack of "High Quality" human capital; poor infrastructure in Peru results in high transportation costs causing an adverse impact on competitiveness. Surprisingly, the sophistication of Peru's exports was not a constraint, and in fact, Peru appeared to do quite well in terms of self discovery.
\end{abstract}

Keywords: Peru, Growth Diagnostics, Micro-economic Constraints, Macro-Economic Constraints, World Development Indicators (WDI), LAC (Latin American and Caribbean) Countries

\section{INTRODUCTION}

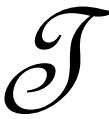

he most fundamental question in development economics is the manner in which a country raises the standard of living for its citizens. A unified, standardized approach to development has, however, proved elusive. Policies and reforms that work well for some economies have proved to be either ineffective or even have unintended negative effects on others. A recent paper by Hausmann, Rodrik and Velasco (2005) pioneers an innovative approach to "growth diagnostics." Hausmann, Rodrik and Velasco argue that "...trying to come up with an identical growth strategy for all countries, regardless of their circumstances, is unlikely to prove productive. ..... The key step is to develop a better understanding of how the binding constraints on economic activity differ from setting to setting......Governments face administrative and political limitations, and their policy making capital is better deployed in alleviating binding constraints than in going after too many targets at once" (p.1-2. $\left.{ }^{1}\right)$.

The objective of this paper is to perform a growth diagnostic for Peru. The methodology is similar to the framework proposed by Hausmann, Rodrik and Velasco. We begin by asking what explains Peru's poor economic performance and then seeking the underlying causes that explain a particular facet of its performance. These causes could be related to low investment which in turn may be explained by factors such as low savings, poor access to capital markets, low returns to investment, poor appropriability, inadequate property right protections, etc. We provide an exhaustive examination of various developmental bottlenecks and constraints. Specifically, we examine savings rates, investment rates, deposit rates, external bond yield spreads, geographical factors, infrastructural constraints, human capital constraints, Mincerian rate of return estimates, tax rates, etc.

\footnotetext{
${ }^{1}$ See also a subsequent paper on "Getting the Diagnosis Right" by Hausmann, Rodrik and Velasco, Finance and Development, Vol.43, No.1, March 2006.
} 
Our objective of this paper is twofold. First, we hope that the analysis contained here would provide policymakers in Peru with a guidepost to framing appropriate economic policy, and second, we hope to provide economic policymakers everywhere with a template to implement a similar type of "growth diagnostic" for their own countries.

\section{PERU'S MACROECONOMIC RECORD (1960-2005)}

We begin by looking at a few stylized facts about Peru's macroeconomic performance. Between the periods of 1960-1975, Peru's economic growth was relatively healthy. The average growth rate in real GDP per capita for the 5-year sub-periods 1961-65, 1966-70 and 1971-75 was 3.18\%, 1.54\% and 2.13\% (see Table 1).

Table 1: Growth in Real GDP Per Capita (Peru versus LAC Countries)

\begin{tabular}{|c|c|c|c|c|c|c|c|c|c|c|}
\hline & $\begin{array}{c}\mathbf{1 9 6 1 -} \\
\mathbf{1 9 6 5}\end{array}$ & $\begin{array}{c}\mathbf{1 9 6 6 -} \\
\mathbf{1 9 7 0}\end{array}$ & $\begin{array}{c}\mathbf{1 9 7 1 -} \\
\mathbf{1 9 7 5}\end{array}$ & $\begin{array}{c}\mathbf{1 9 7 6 -} \\
\mathbf{1 9 8 0}\end{array}$ & $\begin{array}{c}\mathbf{1 9 8 1 -} \\
\mathbf{1 9 8 5}\end{array}$ & $\begin{array}{c}\mathbf{1 9 8 6 -} \\
\mathbf{1 9 9 0}\end{array}$ & $\begin{array}{c}\mathbf{1 9 9 1 -} \\
\mathbf{1 9 9 5}\end{array}$ & $\begin{array}{c}\mathbf{1 9 9 6 -} \\
\mathbf{2 0 0 0}\end{array}$ & $\begin{array}{c}\mathbf{2 0 0 1 -} \\
\mathbf{2 0 0 5}\end{array}$ & $\begin{array}{c}\mathbf{1 9 6 1 -} \\
\mathbf{2 0 0 5}\end{array}$ \\
\hline PERU & $3.18 \%$ & $1.54 \%$ & $2.13 \%$ & $-.39 \%$ & $-1.81 \%$ & $-3.63 \%$ & $3.67 \%$ & $.76 \%$ & $2.57 \%$ & $.89 \%$ \\
\hline LAC & $2.29 \%$ & $2.83 \%$ & $3.40 \%$ & $2.92 \%$ & $-1.60 \%$ & $-.15 \%$ & $1.75 \%$ & $1.64 \%$ & $.97 \%$ & $1.56 \%$ \\
\hline
\end{tabular}

Source: World Development Indicators (WDI)

Though Peru underperformed LAC (Latin American and Caribbean) countries as a whole, its growth record during this period was not unhealthy. Peru's economic problems began in the mid-70s when its growth rate began to turn negative. Over the next decade (1981-90), Peru underwent an extraordinarily adverse macroeconomic transformation. For the two 5-year sub-periods 1981-85 and 1985-90, Peru's growth rate was $-1.81 \%$ and $-3.63 \%$. In 1983, a combination of shocks - world recession, oil price hikes, terms of trade deterioration and rise in global interest rates - led to a decline in real GDP per capita of $14 \%$. In 1989, real GDP per capita again declined by $14 \%$. Over the entire period 1960-2005, the average growth rate of real GDP for Peru was .89\% compared to $1.56 \%$ for LAC.

Even more striking than growth rates is Peru's inflation record. LAC economies, as a whole, performed poorly on the inflationary front. Peru's record, even placed within this context, is extraordinarily poor. Up to the mid-70s, inflation in Peru was lower than that of other LAC countries (see Table 2).

Table 2: Inflation Rates (Peru versus LAC Countries)

\begin{tabular}{|c|c|c|c|c|c|c|c|c|c|c|}
\hline & $\begin{array}{c}\mathbf{1 9 6 1 -} \\
\mathbf{1 9 6 5}\end{array}$ & $\begin{array}{c}\mathbf{1 9 6 6 -} \\
\mathbf{1 9 7 0}\end{array}$ & $\begin{array}{c}\mathbf{1 9 7 1 -} \\
\mathbf{1 9 7 5}\end{array}$ & $\begin{array}{c}\mathbf{1 9 7 6 -} \\
\mathbf{1 9 8 0}\end{array}$ & $\begin{array}{c}\mathbf{1 9 8 1 -} \\
\mathbf{1 9 8 5}\end{array}$ & $\begin{array}{c}\mathbf{1 9 8 6 -} \\
\mathbf{1 9 9 0}\end{array}$ & $\begin{array}{c}\mathbf{1 9 9 1 -} \\
\mathbf{1 9 9 5}\end{array}$ & $\begin{array}{c}\mathbf{1 9 9 6 -} \\
\mathbf{2 0 0 0}\end{array}$ & $\begin{array}{c}\mathbf{2 0 0 1 -} \\
\mathbf{2 0 0 5}\end{array}$ & $\begin{array}{c}\mathbf{1 9 6 1 -} \\
\mathbf{2 0 0 5}\end{array}$ \\
\hline PERU & $8.96 \%$ & $9.79 \%$ & $12.80 \%$ & $51.05 \%$ & $104.93 \%$ & $2342 \%$ & $113 \%$ & $.6 .91 \%$ & $1.94 \%$ & $295 \%$ \\
\hline LAC & $11.57 \%$ & $21.28 \%$ & $15.97 \%$ & $24.03 \%$ & $17.83 \%$ & $22.61 \%$ & $22.21 \%$ & $6.73 \%$ & $6.88 \%$ & $16.57 \%$ \\
\hline
\end{tabular}

Source: World Development Indicators (WDI)

Between 1976 and 1995, inflation in Peru was greater than that of other LAC countries by several orders of magnitude. During the entire 1961-2005 period, the average inflation rate for LAC economies was $16.57 \%$ while that of Peru was an extraordinary 295\%. In fact, given that Peru is part of the sample for LAC countries, the actual discrepancy in inflation between Peru and other LAC countries is even greater than indicated by the numbers above. Dornbusch (1988, p.34) points to one major reason why inflation management was so poor by quoting an astonishing piece of economic analysis from El Peru Heterodoxo: Un Modelo Economico, a book published by the architects of the 1980s economic program.

"An examination of the Peruvian record reveals that periods of moderate inflation are associated with expansionary fiscal policies and periods of major inflation are associated with fiscal restraint. Thus, the record shows exactly the opposite of what is predicted by a theory which explains inflation by fiscal deficits".

It is hardly surprising that inflationary management in Peru was so dismal given the policymakers' lack of understanding of basic economics. 


\section{IS THE HIGH EFFECTIVE COST OF FINANCE A BINDING CONSTRAINT IN PERU? IS LOW SAVINGS AND INVESTMENT THE PROBLEM?}

Traditionally, poor economic growth has been linked to low investment. Perhaps Peru's poor macroeconomic performance could be linked to the fact that it saves and invests a lower percentage of its GDP as compared to other LAC countries. Table 3 computes average annual domestic savings during the period 1990-2005. It is clear from Table 3 that Peru's average annual savings rate of $18.31 \%$ over the last 15 years is better than the average LAC country savings rate of $16.68 \%$. Savings in Peru is neither exceptionally good nor bad; Peru's savings behavior seems about average for LAC countries.

Table 3: Average Annual Savings Growth (1990-2005)

\begin{tabular}{|c|c|}
\hline Country & Savings (\% of GDP) \\
\hline ARG & 18.70 \\
\hline BOL & 10.33 \\
\hline BRA & 21.48 \\
\hline CHL & 26.15 \\
\hline COL & 17.54 \\
\hline CRI & 16.97 \\
\hline DOM & 16.19 \\
\hline ECU & 22.46 \\
\hline SLV & 2.10 \\
\hline GTM & 8.13 \\
\hline GUY & 16.39 \\
\hline HND & 19.58 \\
\hline MEX & 20.71 \\
\hline NIC & 0.45 \\
\hline PAN & 26.43 \\
\hline PRY & 10.99 \\
\hline PER & $\mathbf{1 8 . 3 1}$ \\
\hline URY & 15.01 \\
\hline VEN & 29.00 \\
\hline LAC Average & $\mathbf{1 6 . 6 8}$ \\
\hline
\end{tabular}

Source: World Development Indicators (WDI)

Table 4: Average Annual Growth in Gross Domestic Fixed Capital Formation and Per Capita GDP Growth (1990-2005)

\begin{tabular}{|c|c|c|}
\hline Country & GFCF (as \% of GDP) & GDP Per Capita Growth \\
\hline ARG & 17.41 & 1.40 \\
\hline BOL & 16.06 & 0.60 \\
\hline BRA & 19.40 & 4.11 \\
\hline CHL & 23.16 & 2.22 \\
\hline COL & 17.52 & 2.60 \\
\hline CRI & 19.08 & 1.12 \\
\hline DOM & 22.24 & 1.85 \\
\hline ECU & 19.44 & 1.18 \\
\hline SLV & 16.44 & 2.83 \\
\hline GTM & 14.90 & 0.52 \\
\hline GUY & 29.03 & 1.61 \\
\hline HND & 24.27 & 0.87 \\
\hline MEX & 19.25 & 2.96 \\
\hline NIC & 24.30 & -0.54 \\
\hline PAN & 18.87 & $\mathbf{1 . 7 5}$ \\
\hline PRY & 21.36 & 1.62 \\
\hline PER & $\mathbf{1 9 . 7 4}$ & 0.61 \\
\hline URY & 13.17 & $\mathbf{1 . 6 3}$ \\
\hline VEN & 20.10 & $\mathbf{1 9 . 7 8}$ \\
\hline LAC Average & & \\
\hline
\end{tabular}

Source: Computed from World Development Indicators (WDI) 
Savings need to be translated into productive investments. Table 4 contrasts all LAC countries in terms of their gross capital formation (as \% of GDP) during the period 1990-2005 and then contrasts it with the annual average growth in real per capita GDP growth over the same period. Compared to other LAC countries, Peru's investment is almost equal to the average for LAC countries. In terms of per capita GDP growth, Peru marginally out-performs the LAC average of $1.63 \%$.

The analysis thus far suggests that lack of savings and investment may not constitute the primary explanation for Peru's poor per capita income growth over the last 15 years. In general, Peru's average savings and investment behavior for the past 15 years is not out of the ordinary for LAC countries. The fact that savings and investment is not the primary constraint in Peru is also suggested by the behavior of the current account deficit and interest rates in Peru. Peru's trade balance has been experiencing a surplus since 2002, and its current account balance nearly broke even in 2004, then experienced a surplus in 2005 (see Figure 1). Though these are fairly recent developments, the fact that Peru does not seem to be savings-constrained is highlighted by the behavior of Peru's deposit rate.

Figure 1

\section{CURRENT \& TRADE ACCOUNT BALANCE AS \% OF GDP (1990-2005)}

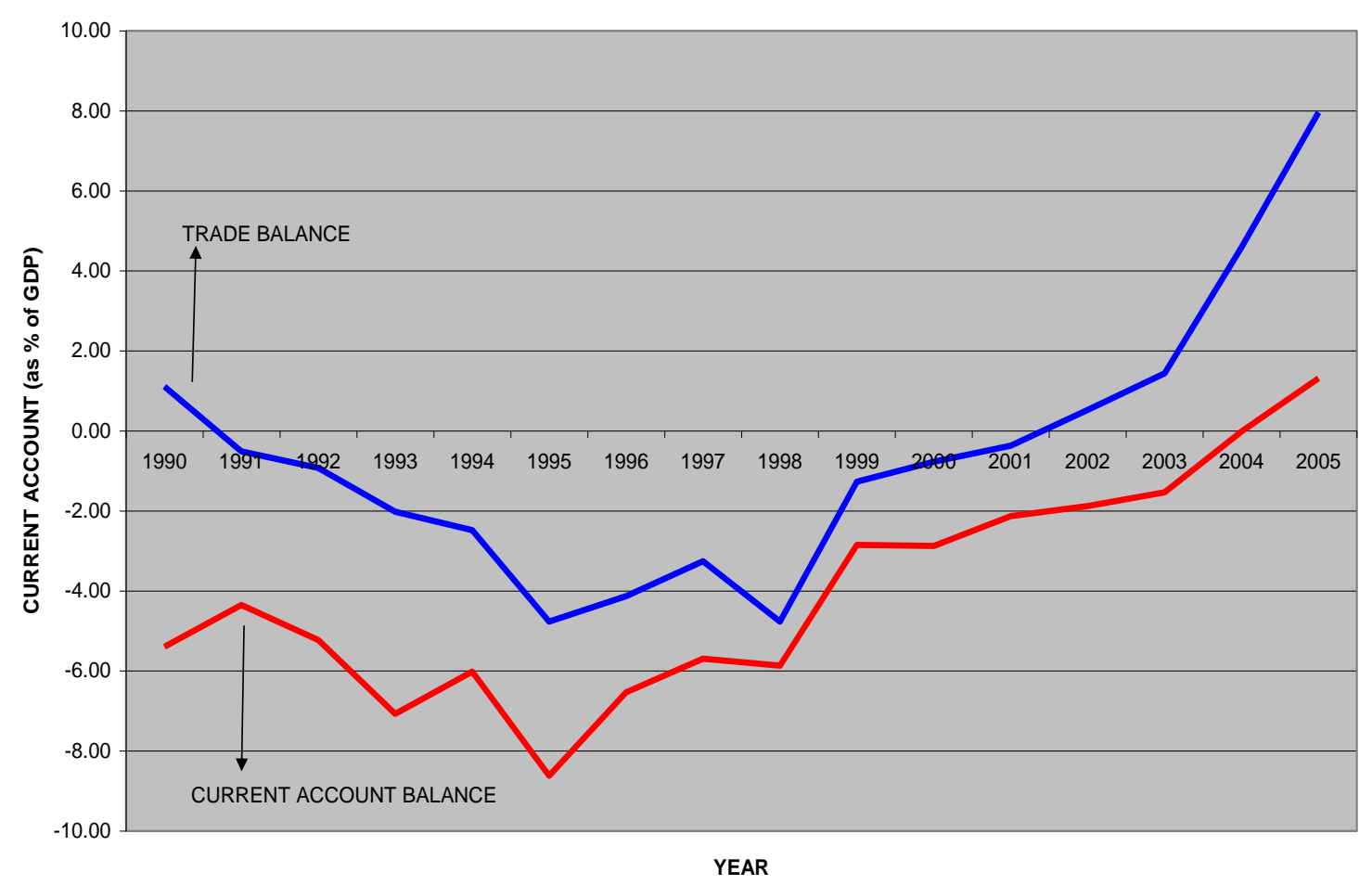

Source: World Development Indicators (WDI)

Peru's deposit rate in 1990 was an astounding $2,440 \%$. Since then, interest rates have been steadily declining. In 2005, the deposit interest rate averaged 3.43\% (see Figure 2). 
Figure 2

DEPOSIT INTEREST RATE IN PERU

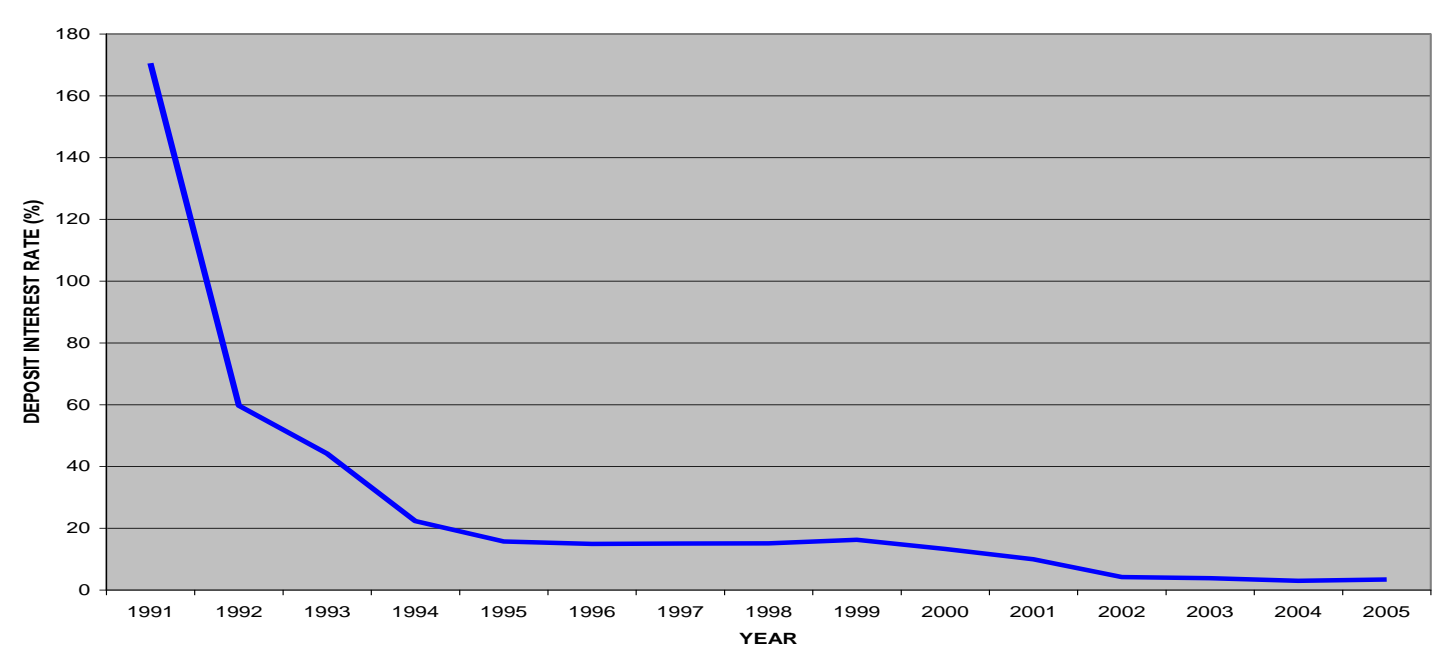

Source: Penn World Tables

Figure 3

EMERGING MARKET BOND YIELD SPREADS

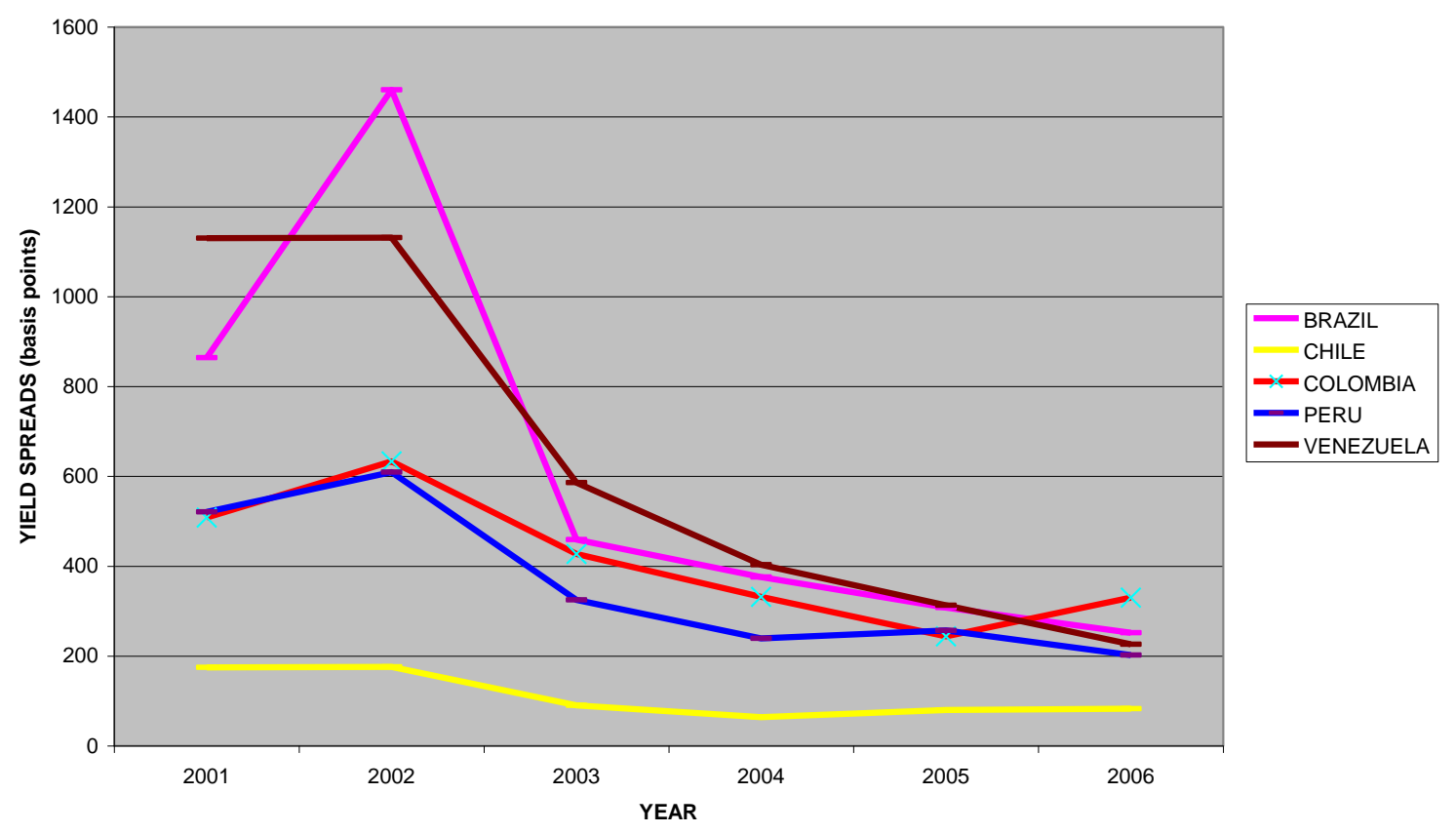

Note: Data for 2006 pertains to June 2006.

Source: Global Financial Stability Report (2006) 


\section{IS EXTERNAL FINANCE THE PROBLEM IN PERU?}

To reinforce the notion that Peru's primary constraint is not lack of access to capital, we turn now to look at Peru's external borrowing situation. In general, Peru's external borrowing rates have not been out of the ordinary for LAC countries. Figure 3 depicts EMBI (Emerging Market Bond Index) global yield spreads for a sample of five LAC countries. As of the second quarter of 2006, Peru's bonds had a lower yield spread than Brazil, Colombia or Venezuela bonds. (It should be noted that as of the second quarter of 2006, Argentina's bonds had a yield spread of 385 basis points while Ecuador's bonds had an even worse yield spread of 506 basis points). As with savings and investment, Peru's bond yield spreads are not out of the ordinary for LAC countries.

A more direct measure than even external bond yield spreads to assess the pressure to finance externally is to consider the actual extent of external bond financing. The data for Peru again does not provide any surprises. Peru's external borrowing over the last half decade has been modest. In 2005, Peru issued external bonds worth U\$ 2157 million. This should be contrasted with Argentina's external bond issue of U\$ 19,093 million and Brazil's issue of U\$ 17,681. Of the total amount of external bonds issued by all LAC countries, Peru's share was about $3.50 \%$. Argentina and Brazil, with far worse yield spreads than Peru, borrowed considerably more from external markets. The data is fairly conclusive that Peru does not seem to be savings-constrained in either domestic or external markets.

\section{ARE LOW RETURNS TO ECONOMIC ACTIVITY THE PROBLEM IN PERU? IS GEOGRAPHY AND TRANSPORT COSTS A PROBLEM?}

The geography of a country can have a major impact on its competitiveness. The costs of conducting trade are impacted by transportation costs which in turn are impacted by a country's geographical characteristics.

We consider a number of indicators to assess the influence of Peru's geography and infrastructure on its competitiveness. Peru is not a landlocked country; in fact, Peru has $2,414 \mathrm{~km}$ of coastline. The major economic activity in Peru occurs along the coastline and the majority of the population centers are located along the coastline. However, there is a large part of the country that is relatively uninhabited with relatively little economic activity occurring. Figure 4 looks at a sample of LAC countries and assesses the relationship between their GDP levels and proximity to a major port. On average, a given geographical point in Peru is roughly about $4000 \mathrm{~km}$ from a major port. In this regard, Peru does much better than several other LAC countries, including Argentina, Chile, Uruguay and Brazil. Clearly, geographical factors, by themselves, do not seem to be the primary economic constraint in Peru.

Figure 4: Distance to Closest Major Port

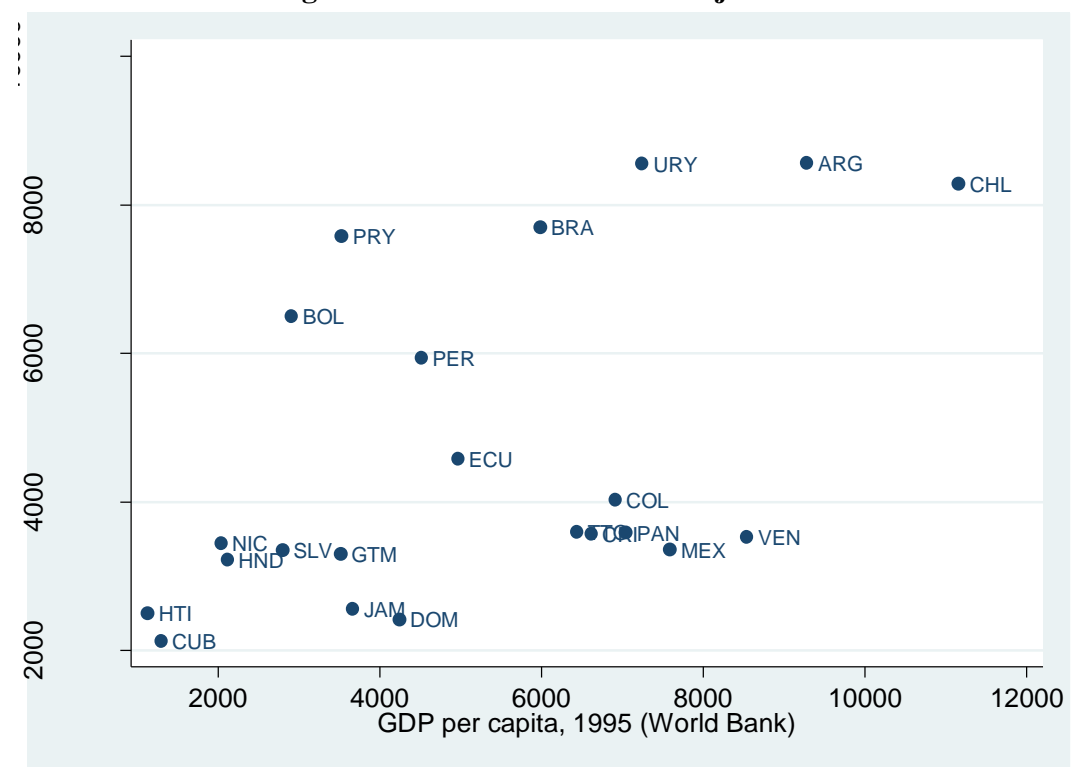

Source: Center for International Development (CID), Harvard University 


\section{IS INFRASTRUCTURE THE PROBLEM IN PERU?}

The geography of a country can have a major impact on its competitiveness. However, a country's geographical endowment, by itself, need not necessarily constitute a binding constraint. A country can overcome the constraints imposed by geography if the quality of a country's infrastructure is high. An exhaustive analysis of infrastructure, geography, transport costs and trade competitiveness is provided by Limao and Venables (2000) who use the CIF/FOB ratio as a proxy for transport costs, insurance and freight. Bonifaz, Gonzalez-Vigil and Urrunaga (2002), however, point out that CIF/FOB costs are only an indirect indicator since limitations in geography can be surmounted by good infrastructure. Bonifaz et al. argue that the CIF/FOB ratio used by Limao and Venables may actually be proxying for infrastructural quality.

"....an improvement in infrastructure is equivalent to a reduction in the geographic distance between countries. On the other hand, it is clear that geographic distances are not necessarily the same as economic distances, but depend, among other factors, on infrastructure presence, its quality, and its regulation"(Bonifaz, Gonzalez-Vigil and Urrunaga, 2002, p.51).

We consider a number of indicators to assess the influence of Peru's infrastructure on its competitiveness. Table 5 presents results from the Global Competitiveness Report (2005-6) on Railroad, Port and Air Transport Efficiency Indicators for a sample of LAC countries.

Table 5: Infrastructure Efficiency Indicators in LAC Countries (2005)

\begin{tabular}{|l|c|c|c|}
\hline \multicolumn{1}{|c|}{ Country } & Railroad Infrastructure & Port Infrastructure & Air Transport Infrastructure \\
\hline Argentina & 2.7 & 3.6 & 4.3 \\
\hline Bolivia & 1.8 & 1. & 3.7 \\
\hline Brazil & 1.8 & 2.7 & 4.5 \\
\hline Colombia & 1.4 & 2.8 & 4.7 \\
\hline Costa Rica & 1.2 & 2.3 & 4.5 \\
\hline Chile & 2.7 & 4.9 & 5.7 \\
\hline Dominican Republic & 1.1 & 3.4 & 4.8 \\
\hline Ecuador & 1.2 & 2.9 & 4.4 \\
\hline El Salvador & 1.5 & 3.9 & 5.6 \\
\hline Mexico & 2.2 & 3.3 & 4.9 \\
\hline Paraguay & 1.0 & 2.3 & 2.9 \\
\hline Peru & $\mathbf{1 . 6}$ & $\mathbf{2 . 1}$ & $\mathbf{3 . 2}$ \\
\hline Uruguay & 1.5 & 4.4 & 3.5 \\
\hline Venezuela & 1.3 & 2.8 & 4.0 \\
\hline LAC AVERAGE & $\mathbf{1 . 6 4}$ & $\mathbf{3 . 0 6}$ & $\mathbf{4 . 3 4}$ \\
\hline
\end{tabular}

Note: 1 = Underdeveloped; $7=$ Efficient and Extensive as the World's Best

Source: The Global Competitiveness Report, 2005-2006

The results in Table 5 indicate that Peru's railroad infrastructure is about average for LAC countries, but its port and air transport infrastructural facilities are worse than the other LAC countries represented in the sample. Thus, infrastructure could be a potential bottleneck in explaining Peru's poor economic performance.

Since infrastructure seems to be a constraint, we examine this aspect further. The 2002 "Investment Climate Assessment" (ICA) for Peru, conducted by the World Bank, indicates that poor quality infrastructure is a major constraint in Peru. In a 2001 World Bank Survey, logistics costs comprised 28\% of business expenses in Peru, while logistical costs in Chile comprised only $15 \%$ of costs. Similarly, a study conducted by the Inter-American Development Bank (IDB) on the quality of road infrastructure in LAC countries ranks Peru as second only to Bolivia in terms of poor road infrastructure (see Figure 5). The Investment Climate Assessment Survey also notes that only $13 \%$ of the roads in Peru are paved and transport time can vary greatly. 
Figure 5

\section{Ranking of Road Infrastructure in Latin America}

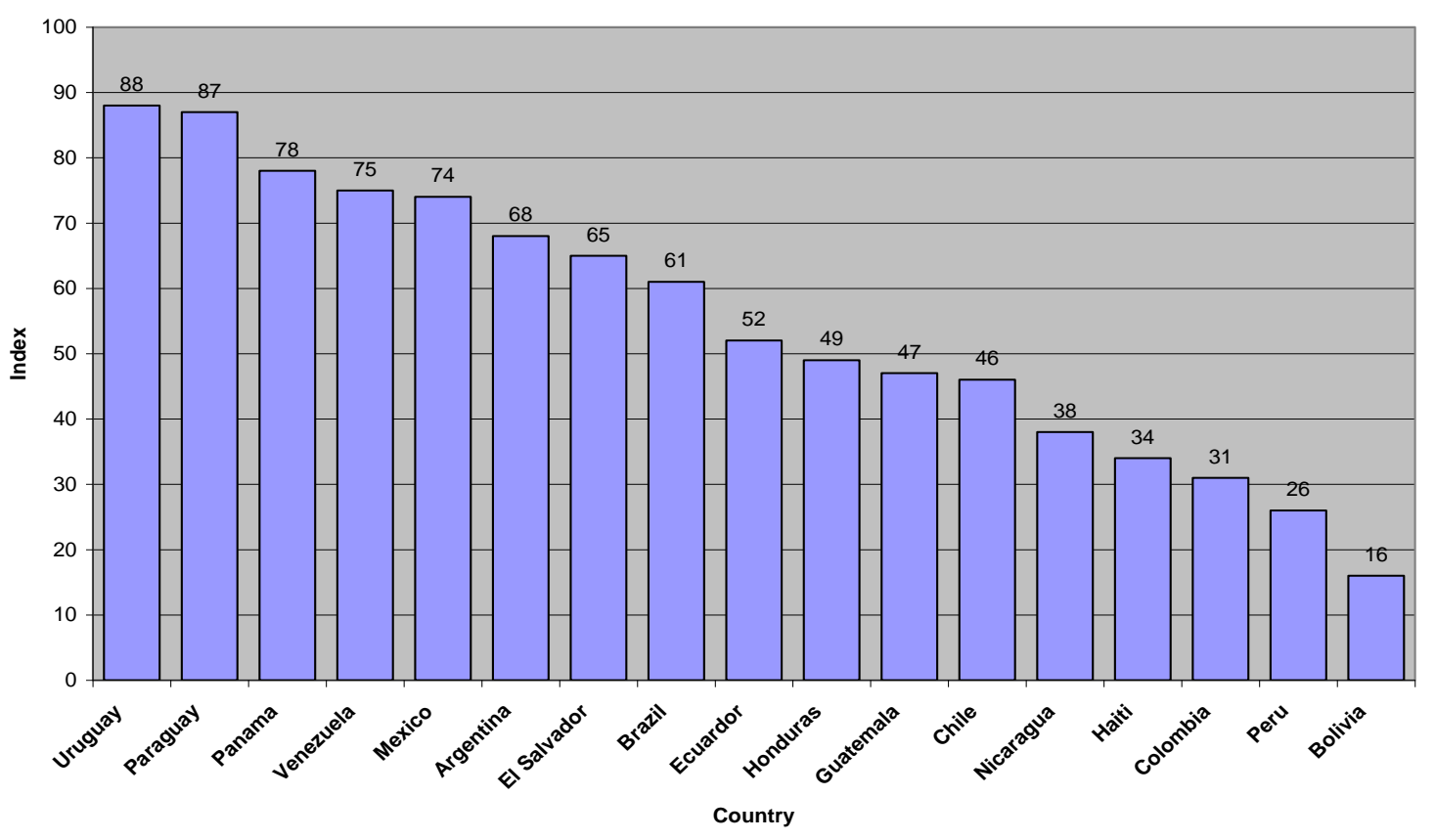

Source: Infrastructure Report, Inter-American Development Bank, Mimeo 2000

Figure 6

Transport Costs to Export Textiles to the US Compared to Taiwan (Numbers in Parenthesis are average maritime distances to the US)

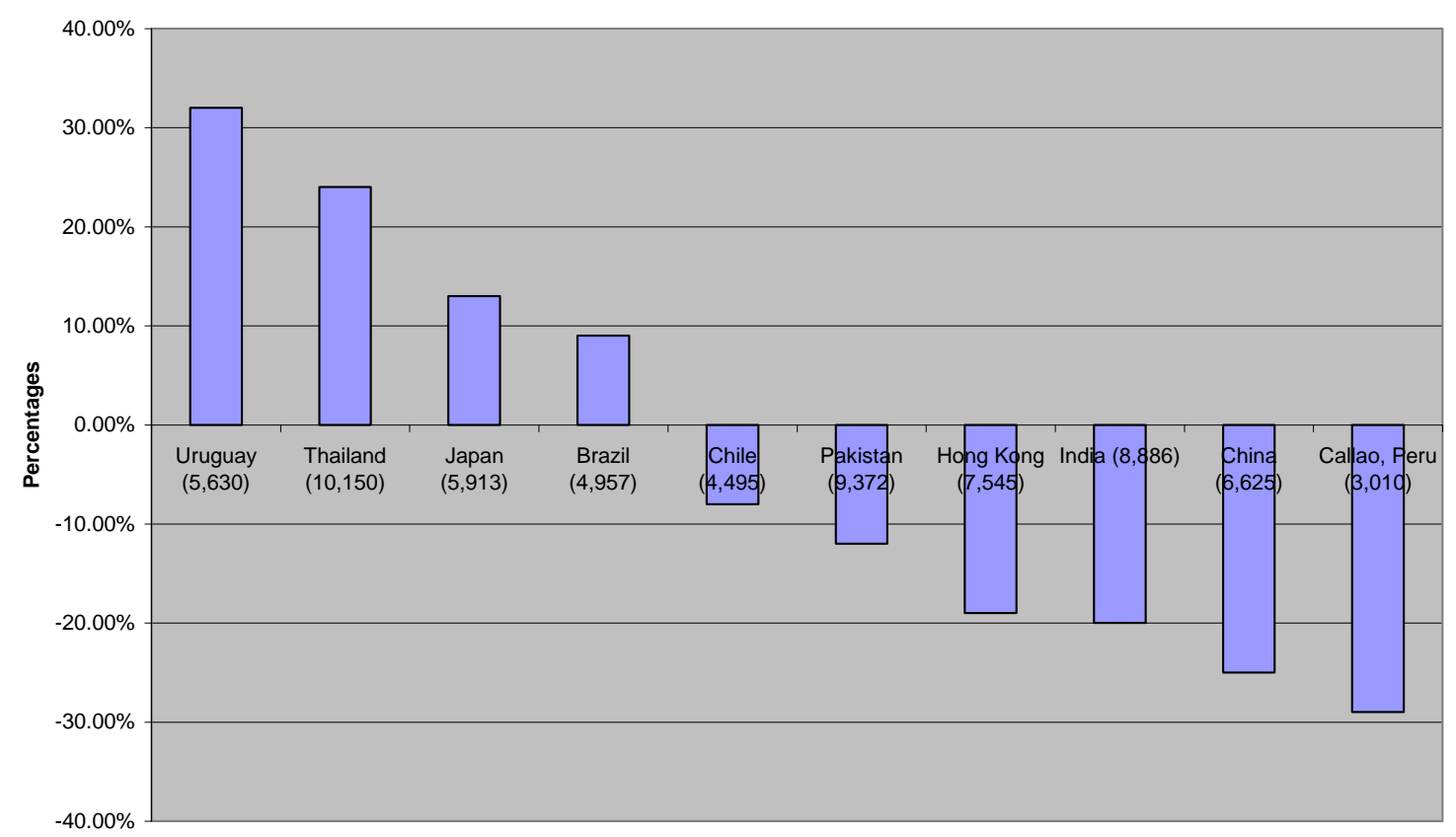


The link between poor infrastructure, high transport costs and the resulting lack of competitiveness in international markets is highlighted in a study conducted by the U.S. Department of Transportation on the cost of exporting textiles to the U.S. (as compared to Taiwan). Figure 6 shows that Peru's major port of Callao has higher transport costs than other ports worldwide, even though Peru is far closer than the other markets in the sample. For instance, both Uruguay and Thailand are almost twice as far from the U.S. as Peru, but yet they have a cost advantage of $31 \%$ and $23 \%$ as compared to Peru's cost disadvantage of $29 \%$. The study is a stark reminder that Peru's infrastructure, far more than its geography, is a primary constraint on its competitiveness. Peru's ability to import and export efficiently is adversely affected by the bottlenecks in its infrastructure.

The analysis above indicates that infrastructure and transport costs are clearly a problem in Peru. Moreover, in relation to other LAC countries, Peru has been investing a relatively small percentage of its GDP in infrastructural improvements. At the end of the 1990s, Chile was investing $2 \%$ of its GDP in infrastructure improvements, while Ecuador and Brazil invested 1\% of their GDP in infrastructural development. The equivalent figure in Peru was $0.20 \%$. $^{2}$ Thus, not only is the quality of Peru's infrastructure poor; it seems likely that the quality gap between Peru and other LAC countries will widen even further in the future.

\section{IS POOR HUMAN CAPITAL THE PROBLEM IN PERU?}

The relationship between education and human capital and between human capital and income growth are well documented in the development economics literature. Among the best known studies in this area are papers by Barro (1991), IADB (1993), and Barro and Salai-Martin (1995).

Generally speaking, the labor force in LAC countries has lower educational attainment than in countries of similar income levels. The average schooling of a work force participant in OECD countries is 11.1 years. In East Asia (excluding China) average schooling is 8.1 years, while the average in LAC countries is only 5.4 years. Figure 7 considers the years of schooling for populations over 25 years of age for all LAC countries. (It should be noted that the data here pertains to population over age 25 and therefore includes a sample of participants who have retired from the workforce. However, it is a reasonable proxy of the educational attainment of the specific country's labor force).

Figure 7

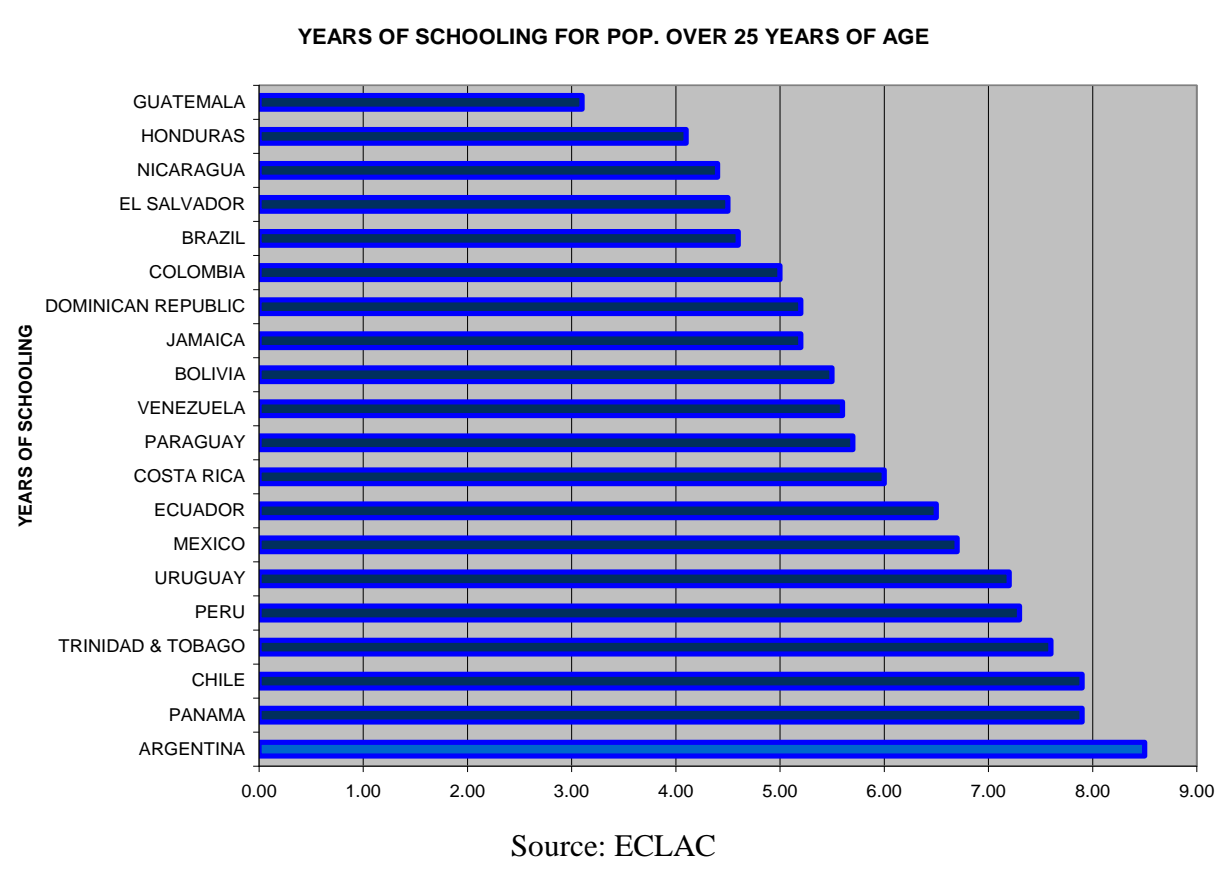

2 “Peru Investment Climate Assessment, " International Financial Corporation (IFC), 2002. pp. 40. 
Human capital, as represented by years of schooling, does not seem to be an issue in Peru. Given the LAC country's average of 5.9 years, Peru's average of about 7 years of schooling places its work force among the better educated work forces in Latin America.

However, years of schooling of the labor force alone does not indicate if human capital constitutes a growth bottleneck. Rates of return on human capital are a better indicator of the role played by human capital in a country's economic development. In contrast to many of the previous indicators, the picture in Peru is unambiguous. The table below reports estimated Mincerian Rates of Return on Human Capital ${ }^{3}$ from a variety of different studies for a sample of LAC countries. The Mincerian rates are complied from various country household surveys using the most recent estimates available.

Table 6: Mincerian Returns to Higher Education by Different Levels (Social vs. Private)

\begin{tabular}{|l|c|c|}
\hline \multicolumn{1}{|c|}{ Country } & Social Returns & Private Returns \\
\hline Argentina & 7.6 & 14.9 \\
\hline Bolivia & 13 & 19 \\
\hline Brazil & 21.4 & 28.2 \\
\hline Colombia & 14 & 21.7 \\
\hline Costa Rica & 9.0 & 12.9 \\
\hline Chile & 14 & 20.7 \\
\hline Ecuador & 9.9 & 12.7 \\
\hline El Salvador & 8.0 & 9.5 \\
\hline Mexico & 11.1 & 15.7 \\
\hline Paraguay & 10.8 & 13.7 \\
\hline Peru & - & $\mathbf{4 0 . 0}$ \\
\hline Uruguay & 10.3 & 12.8 \\
\hline Venezuela & 6.2 & 11.0 \\
\hline
\end{tabular}

Source: Ed Stats of the World Bank

What is immediately obvious is that the return to private education in Peru is almost twice as much as the LAC average and more than one-third higher than even it's closest competitor, Brazil. Clearly, the return to private education in Peru could not be so high if higher education was not a bottleneck. The excess returns to higher education are a symptom of a country that is constrained by lack of access to high quality human capital. Our analysis then seems to indicate that access to human capital seems to be a significant constraint to economic growth in Peru.

\section{ARE MACRO AND MICRO RISKS THE PROBLEM IN PERU? IS APPROPRIABILITY A PROBLEM?}

Macroeconomic risk arises from volatility, which is primarily related to inflation. LAC economies, as a whole, performed poorly on the inflationary front. Peru's record, even placed within this context, is extraordinarily poor. Up to the mid-70s, inflation in Peru was lower than that of other LAC countries. Between 1976 and 1995, however, inflation in Peru was greater than that of other LAC countries by several orders of magnitude. Over the entire 1961-2005 period, the average inflation rate for LAC economies was $16.57 \%$, while that of Peru was an extraordinary $295 \%$.

However, there has been a remarkable turnaround in the last few years. During the period 2001-2005, the average inflation rate in Peru was $1.94 \%$ compared to $6.88 \%$ for LAC countries. Clearly, over the last five years, there has been somewhat of a turnaround in Peru's macroeconomic performance. Therefore, while inflation was clearly a problem in the past, it currently does not seem to be much of an issue.

\footnotetext{
${ }^{3}$ See Mincer, J. (1974), Schooling, Experience and Earnings, New York: National Bureau of Economic Research.
} 
Much like inflation rates, the exchange rate in Peru has also come into control within the past few years after extreme volatility in the early 1990s. Due to high inflation and interest rates, the domestic currency was worth very little relative to the U.S. Dollar. However, after an extreme devaluation, the real exchange rate has stabilized.

Even though the macro environment, with regard to inflation and exchange rates, has stabilized within the last few years, there is a considerable degree of uncertainty with respect to government laws, regulations and economic policies. There is little doubt that the microeconomic business climate in Peru constitutes a major bottleneck to Peru's development. Survey upon survey highlights the uncertain investment and business climate in Peru. Table 7 below compares corporate and personal tax rates, customs duties, tax revenues and business profit taxes for a sample of Latin American countries. Though Peru is not the worst among LAC countries, there are clearly issues of appropriability in Peru.

Table 7: Tax Rates and Tax Revenues in Peru

\begin{tabular}{|l|c|c|c|c|c|}
\hline Country Name & Corporate Rate & Personal Rate & Customs Duties & Tax Revenue & Business Profit Tax \\
\hline Argentina & 35 & 35 & 4.94 & 14.21 & 97.90 \\
\hline Bolivia & 25 & 13 & 5.05 & 15.12 & 64.00 \\
\hline Brazil & 15 & 27.5 & 5.93 & 12.15 & 147.90 \\
\hline Chile & 16.5 & 40 & 2.85 & 15.74 & 46.70 \\
\hline Colombia & 36.7 & 35 & 6.51 & 13.94 & 75.10 \\
\hline Costa Rica & 30 & 30 & 6.26 & 13.44 & 54.30 \\
\hline Dominican Republic & 25 & 25 & 16.18 & 14.67 & 57.20 \\
\hline Ecuador & 25 & 25 &.. &.. & 33.90 \\
\hline El Salvador & 25 & 30 & 10.04 & 10.98 & 32.20 \\
\hline Mexico & 33 & 33 & 5.13 &.. & 31.30 \\
\hline Nicaragua & 25 & 25 & 6.08 & 15.70 & 54.30 \\
\hline Panama & 30 & 30 & 23.67 & 11.19 & 32.90 \\
\hline Paraguay & 30 &.. & 18.34 & 13.29 & 37.90 \\
\hline Peru & 30 & 30 & 7.70 & 18.48 & 50.70 \\
\hline Uruguay & 35 &.. & 7.07 & 11.54 & 80.20 \\
\hline Venezuela, RB & 34 & 34 & 7.35 & 48.90 \\
\hline
\end{tabular}

Source: ECLAC

Peru's recent political history has also been unfortunately violent, marred by the active operation of extremist, terrorist organizations like Sendero Luminoso, Sendero Rojo and the Tupac Amaru Revolutionary movement. The turmoil in Peru has lead to a situation in which property rights are not effectively protected and the rule of law is weak. The U.S. Department of Commerce reports that:

"......the judicial system is often extremely slow to hear cases and to issue decisions....allegations of corruption and outside interference in the judicial system are common....investors have found that contracts are often difficult to enforce in Peru".

To measure the quality of Peru's institutions, we use the Index of Economic Freedom - an index developed jointly by the Heritage Foundation and the Wall Street Journal, which is perhaps the most comprehensive index of economic freedom currently available. The Economic Freedom Index (EFI) is created from a numerical ranking based on a comprehensive list of 10 institutional factors. The numerical rankings for each institutional factor could fall into either of four broad categories:

Free: $\quad$ A score of 1.99 or less

Mostly Free: $\quad$ A score of 2 to 2.99

Mostly Unfree: $\quad$ A score of 3 to 3.99

Repressed: $\quad$ A score of 4 or higher 
Thus, lower scores indicate greater freedom. (By this measure, Hong-Kong was the freest country in the world, while North Korea was the most repressed.) The institutional factors measured by the EFI, the variables that go into measuring each institutional factor, as well as the score received by Peru in each category, are shown in Table 8.

Table 8: Economic Freedom Index (2005) Values for Peru

\begin{tabular}{|c|c|c|}
\hline & \\
\hline Institutional Factor & Variables Included in Computing Institutional Factor Score & Peru's Score \\
\hline Trade Policy Index & $\begin{array}{l}\text { Weighted Average Tariff Rates, Non-Tariff Barriers, Corruption } \\
\text { in Customs, etc }\end{array}$ & 4.0 \\
\hline Fiscal Burden of Government Index & $\begin{array}{l}\text { Personal Tax Rates, Corporate Tax Rates, Ratio of Govt. } \\
\text { Expenditure to GDP, etc. }\end{array}$ & 2.50 \\
\hline Govt. Intervention Index & Govt. Consumption as \% of GDP, Govt. Ownership, etc. & 2.0 \\
\hline Monetary Policy Index & Weighted Average Inflation Rates over a 10 year period & 1.0 \\
\hline Capital Flow \& Investment Index & $\begin{array}{l}\text { Investment Code, Foreign Ownership Restrictions, Capital } \\
\text { Restrictions, etc. }\end{array}$ & 2.0 \\
\hline Banking and Finance Index & $\begin{array}{l}\text { Govt. Ownership of Financial Institutions, Foreign Ownership } \\
\text { Restrictions, Govt. Regulations that inhibit financial activity, etc. }\end{array}$ & 2.0 \\
\hline Wage and Price Index & $\begin{array}{l}\text { Minimum Wage Laws, Price Ceilings, Price Controls, Govt. } \\
\text { Subsidies, etc. }\end{array}$ & 2.0 \\
\hline Property Rights Index & $\begin{array}{l}\text { Commercial Code, Expropriation, Govt. Influence of Judiciary, } \\
\text { Corruption, etc. }\end{array}$ & 4.0 \\
\hline Regulation Index & $\begin{array}{l}\text { Licensing Requirements, Bureaucratic Corruption, Labor Laws, } \\
\text { Environmental and Consumer Protections, etc. }\end{array}$ & 4.0 \\
\hline \multirow[t]{2}{*}{ Informal Market Index } & $\begin{array}{l}\text { Extent of Smuggling, Black Market Activities, Intellectual } \\
\text { Property Rights, etc. }\end{array}$ & 4.0 \\
\hline & & $\begin{array}{c}\text { Composite EFI } \\
\text { Score }=2.75\end{array}$ \\
\hline
\end{tabular}

From Table 8, it is clear that even though Peru has done relatively well in terms of the indices relating to monetary policy, capital flows, banking/finance and wages/prices, it scores poorly for the institutional quality of property rights enforcement, trade restrictions, regulatory environment and the extent of black market activities.

A recent World Bank study ("Microeconomic Constraints to Growth", June 15, 2004) utilizes a unique data set on manufacturing firms to come to the conclusion that both the macroeconomic and microeconomic environment in Peru constitutes a serious constraint to growth in Peru.

The report goes on to quantify the real impact of such macroeconomic uncertainty. It calculates, for instance, that for each one point rise in uncertainty (on a 5-point scale), investment in machinery dropped by an astounding $16 \%$ and business profitability by $2 \%$. Thus, there is little doubt that an uncertain macroeconomic and microeconomic environment constitutes a serious constraint on Peru's growth.

From the discussion above it seems reasonable to conclude that the macro and microeconomic environment in Peru constitutes a binding constraint and relieving this constraint would lead to significant economic growth in Peru.

\section{CONCLUSION}

1. Peru is not savings or investment constrained in either domestic or international markets. This is indicated by the fact that domestic interest rates and external bond yield spreads are relatively low.

2. Peru is constrained with regard to high quality human capital. Peru has among the lowest retention rates in Latin America for scientists and engineers. The fact that Peru is constrained in terms of human capital is signaled by the very high Mincerian rates of return to human capital. 
3. The sophistication of Peru's exports is not a constraint. In fact, Peru seems to have done well in terms of self-discovery.

4. Poor infrastructure in Peru is a constraint. The infrastructural constraints result in very high transport costs which adversely impact its competitiveness.

5. The micro and macroeconomic environment in Peru is perhaps the most binding constraint of all. Survey after survey reveals this aspect. A recent World Bank study and a survey by the World Economic Forum confirm our findings.

\section{AUTHOR INFORMATION}

Sudhakar Raju is Professor of Finance at Rockhurst University in Kansas City, MO. He teaches graduate courses in Corporate Finance, Financial Policy and Derivatives Markets. He has served as a Consultant to several organizations including the World Bank, United Nations Development Program (UNDP) and the Chicago Board of Trade.

Brian D. Fitzpatrick is a professor of finance for the Helzberg School of Management at Rockhurst University in Kansas City, Missouri. He earned his Ph.D. in Finance with a concentration in Investments from Saint Louis University. Dr. Fitzpatrick spent ten years in the Investment field including positions with two major Wall Street wire houses, as well as serving as senior vice president for both Financial Corporation of America and Commerce Bancshares. Brian has won the Rockhurst University's Teaching Excellence Award, and he has published in nine different fields.

\section{REFERENCES}

1. Arellano, Jose Pablo (2005), "International Competitiveness and Education in Latin America and the Caribbean Countries", Global Competitiveness Report 2005-6, World Economic Forum, Geneva, Switzerland, p.62-79.

2. Barro, Robert (1991), "Economic Growth in a Cross Section of Countries", Quarterly Journal of Economics, Vol.106, 407-43.

3. Barro, Robert and Xavier Sala-i-Martin, Economic Growth, New York: McGraw-Hill, 1995.

4. Bonifaz, Gonzalez-Vigil and Urrunaga (2005), "Logistics and Markets: Overcoming the Challenges of a Difficult Market”, Global Competitiveness Report 2005-6, World Economic Forum, Geneva, Switzerland, p.45-61.

5. Dornbusch, R., "Peru on the Brink", Challenge, Nov. /Dec. 1988, Vol.31, No.6, pp.31-37

6. Hausmann, Ricardo and Dani Rodrik (2002), "Economic Development as Self Discovery," National Bureau of Economic Research, No. 8962.

7. Hausmann, R., D.Rodrik and A. Velasco, "Getting the Diagnosis Right" Finance and Development, Vol.43, No.1, March 2006.

8. Hausmann, R., D.Rodrik and A. Velasco, "Growth Diagnostics”. Reproduced Harvard University, Revised March 2005..

9. Inter-American Development Bank (IADB), 1993, Economic and Social Progress in Latin America, Johns Hopkins Press.

10. Klinger and Lederman (2004), "Discovery and Development: An Empirical Exploration of 'New' Products," World Bank Policy Research Working Paper 3450, November 2004.

11. Mincer, J. (1974), Schooling, Experience and Earnings, New York: National Bureau of Economic Research.

12. Limao, Nuno and Venables, Anthony, "Infrastructure, Geographical Disadvantage, Transport Costs, and Trade", World Bank Economic Review, Vol.15, No.3, 451-479.

13. The Global Competitiveness Report 2005-6, World Economic Forum, Geneva, Switzerland.

14. PERU - Microeconomic Constraints to Growth: The Evidence from the Manufacturing Sector, June 15, 2004, Report No - PE, World Bank, Washington, D.C.

15. Peru Investment Climate Assessment, International Financial Corporation, 2002.

16. World Bank Development Indicators, World Bank.

17. Penn World Tables.

18. Peru Household Survey (1994), Living Standards Measurement Study, World Bank. 
NOTES 